\title{
Macronutrient Suppression in Nutrient Solution Alters the Growth and Citral Content of Cymbopogon flexuosus
}

\author{
Vauvenargues Lopes ${ }^{1}$, Alexandre Alves de Carvalho ${ }^{1}$, Suzan Kelly Vilela Bertolucci ${ }^{2}$, \\ Heitor Luiz Heiderich Roza ${ }^{1}$, Felipe Campos Figueiredo ${ }^{3}$ \& José Eduardo Brasil Pereira Pinto ${ }^{1}$ \\ ${ }^{1}$ Laboratory of Plant Tissue Culture and Medicinal Plants, Department of Agriculture, Federal University of \\ Lavras, Lavras, Brazil \\ ${ }^{2}$ Laboratory of Phytochemistry and Medicinal Plants, Department of Agriculture, Federal University of Lavras, \\ Lavras, Brazil \\ ${ }^{3}$ Laboratory of Fertilizer, Department of Soil Science, Federal Institute of Minas Gerais South, Muzambinho, \\ Brazil \\ Correspondence: José Eduardo Brasil Pereira Pinto, Laboratório de Cultura de Tecidos e Plantas Medicinais, \\ Departamento de Agricultura, Universidade Federal de Lavras, Câmpus Universitário, Caixa Postal 3037, CEP \\ 37200-000, Lavras, Brazil. E-mail: jeduardo@ufla.br
}

\author{
Received: February 8, 2019 Accepted: March 14, 2019 Online Published: May 15, 2019 \\ doi:10.5539/jas.v11n6p320 \\ URL: https://doi.org/10.5539/jas.v11n6p320
}

The research is financed by CAPES, CNPq, and FAPEMIG.

\begin{abstract}
Cymbopogon flexuosus Stapf is a medicinal species cultivated on several continents. The essential oil extracted from its leaves has relevant commercial value and is widely used in flavoring agents, fragrances, perfumery, cosmetics, soaps, and detergents as well as in the pharmaceutical industry. This study evaluated the effect of macronutrient suppression on the growth, visual diagnosis, content, and chemical composition of $C$. flexuosus essential oil in a hydroponic culture. A completely randomized design with four replicates was used, with three plants per pot in each replicate. The treatments were characterized by suppressing the macronutrients, N, P, K, Ca, $\mathrm{Mg}$, and $\mathrm{S}$, under the missing element technique. After 90 days of cultivation, the deficiency symptoms were photographed and characterized. The dry biomass of the roots and shoot, root-to-shoot ratio, number of tillers, leaf analysis, content, yield, and chemical composition of the essential oil were evaluated. Macronutrient suppression in a hydroponic culture influenced growth and chemical composition of $C$. flexuosus essential oil. Total biomass production was more limited in potassium and magnesium omission. Suppressing sulfur promoted an increase in content and yield of essential oil. The highest citral content was observed in phosphorus and nitrogen omission.
\end{abstract}

Keywords: aromatic plant, nutrition, hydroponics, lemongrass

\section{Introduction}

Cymbopogon flexuosus Stapf, family Poaceae (Gramineae), is popularly known as Indian lemongrass, Cochin grass, or Malabar grass (Marigowda et al., 2016). It grows on several continents and originates in south Asia, southeast Asia, and Australia (May et al., 2008). The essential oil extracted from this species is widely used and marketed in the pharmaceutical, food, hygiene, and cosmetics industries (Ganjewala \& Luthra, 2010). The estimated world production is 800 to 1300 tons of the oil per year, with $40 \%$ of this production coming from China and Indonesia (Joyce et al., 2015).

Lemongrass oil has sedative, digestive, antirheumatic, calming, antifebrile, carminative, stomach, analgesic, antispasmodic, and antimicrobial activities (May et al., 2008; Meena et al., 2016). In addition, it is a good candidate for innovative therapeutic strategies against cancer because of its cytotoxic and anticancer potential (Sharma et al., 2009; Marigowda et al., 2016). The citral monoterpene, a racemic mixture of the geranial and neral isomers, corresponds to $75-85 \%$ of the oil's chemical composition. Its biological properties, including insecticidal and larvicidal activities against Aedes aegypti (Vera et al., 2014), antifungal activity (Ganjewala \& Luthra, 2010), and bactericidal and antimicrobial activities (Adukwu et al., 2016), are attributed to this major constituent of 
lemongrass essential oil. According to Joyce et al. (2015), this monoterpene inhibits Saccharomyces cerevisiae fermentation in alcohol biorefineries.

Mineral nutrients perform essential and specific functions, and their deficiencies or toxicities are observed via symptoms often characteristic of each nutrient (Oliveira et al., 2009). The nutrient solution and the missing element technique are used in scientific research mainly to obtain symptomatological information on a plant's deficiency of a certain nutrient or toxicity caused by that nutrient, aiding in improving the production system (Andriolo et al., 2002; Alves et al., 2008). Maia et al. (2014) observed that the number of studies on culturing medicinal plants in hydroponics is increasing in scientific research, and managing these cultures is feasible. These authors found that the hydroponic system enables seedling production without agrochemical residues and increases the content of active principles of interest. Studies on nutrient solutions have been conducted on several medicinal species, including Mentha arvensis (Carvalho et al., 2016), Achillea millefolium (Alvarenga et al., 2015), Coriandrum sativum (Daflon et al., 2014), Ocimum sp. (Amaral et al., 2015), Maytenus ilicifolia (Benedetti et al., 2009), and Arrabidaea chica (da Silva Júnior et al., 2011).

In this context, this study evaluated the growth, production, and chemical composition of essential oil from $C$. flexuosus and characterized the visual symptoms of macronutrient deficiency in hydroponic cultures using the missing element technique.

\section{Material and Methods}

\subsection{Procedure, Harvesting, and Vegetative Analysis}

The experiment was conducted in an $18.5 \times 13 \mathrm{~m}$ plastic greenhouse, located in a north-south position at the Laboratory of Culture of Vegetable Tissues and Medicinal Plants of the Department of Agriculture of the Federal University of Lavras (DAG/UFLA), in the southern region of Minas Gerais state, at an altitude of $918 \mathrm{~m}$, latitude $21^{\circ} 14^{\prime} \mathrm{S}$ and longitude $45^{\circ} 00^{\prime} \mathrm{W}$.

Cymbopogon flexuosus mother plants belonging to the Medicinal Plants Garden of UFLA were identified and compared with the exsiccate deposited by the Agronomic Institute of Campinas IAC Herbarium under the number 45335. The seedlings were propagated by clump division, and each tiller was approximately $8 \mathrm{~cm}$ high. The propagules were cultured in trays of expanded polystyrene containing the commercial substrate Plantmax ${ }^{\circledR}$ and were kept in a greenhouse with $60 \%$ shading. After 60 days, the plants were adapted in 25 and $50 \%$ Hoagland and Arnon (1950) nutrient solution, for one week each. They were then placed in individual 6-liter pots containing $100 \%$ of the solution's ionic strength, and the missing element technique was applied for 90 days. A completely randomized experimental design was used with seven treatments and four replications. The treatments were the complete solution (control) and macronutrient suppression of $\mathrm{N}, \mathrm{P}, \mathrm{K}, \mathrm{Ca}, \mathrm{Mg}$, and $\mathrm{S}$. The experimental plot comprised three plants per pot.

The solutions were prepared with pure reagents. A modified Hoagland and Arnon solution (1950) was used containing the following concentrations in the complete solution: $210.105 \mathrm{mg} \mathrm{L}^{-1} \mathrm{~N}, 30.974 \mathrm{mg} \mathrm{L}^{-1} \mathrm{P}, 156.392 \mathrm{mg}$ $\mathrm{L}^{-1} \mathrm{~K}, 160.4 \mathrm{mg} \mathrm{L}^{-1} \mathrm{Ca}, 48.61 \mathrm{mg} \mathrm{L}^{-1} \mathrm{Mg}, 32.06 \mathrm{mg} \mathrm{L}^{-1} \mathrm{~S}, 500 \mu \mathrm{g} \mathrm{L}^{-1} \mathrm{~B}, 20 \mu \mathrm{g} \mathrm{L}^{-1} \mathrm{Cu}, 648 \mu \mathrm{g} \mathrm{L}^{-1} \mathrm{Cl}, 5022 \mu \mathrm{g} \mathrm{L}^{-1}$ $\mathrm{Fe}, 502 \mu \mathrm{g} \mathrm{L}^{-1} \mathrm{Mn}, 11 \mu \mathrm{g} \mathrm{L}{ }^{-1} \mathrm{Mo}$, and $50 \mu \mathrm{g} \mathrm{L}^{-1} \mathrm{Zn}$. In the treatment solutions, the nutrient concentrations were identical to those of the complete solution, except for the suppressed nutrient. The solutions were renewed fortnightly and replenished by adding deionized water when necessary. The pots were black plastic, and their exteriors were painted with aluminum paint to prevent heating the nutrient solution. An air compressor was used for aeration, and a cylindrical porous stone measuring $1 \mathrm{~cm}$ in diameter and $2 \mathrm{~cm}$ long was placed at the end of each hose.

The symptoms were observed, described and photographed at the end of the experimental period. The harvested material was dehydrated in a forced ventilation oven at $40{ }^{\circ} \mathrm{C}$ for three days. Leaf dry biomass (LDB), leaf base dry biomass (LBDB), shoot dry biomass (SDB), root dry biomass (RDB), and total dry biomass (TDB) were evaluated in grams per plant. The leaf base dry biomass (LBDB) corresponds to the sectioned region between the root and leaf. Shoot dry biomass (SDB) was calculated by the sum of the leaf dry biomass and leaf base dry biomass (LDB+LBDB). Root-to-shoot ratio (R:S), number of tillers (NT) and the percentage of relative production of total dry biomass (RPTDB) were also determined, and the complete treatment corresponded to $100 \%$. The root-to-shoot ratio $(\mathrm{R}: \mathrm{S})$ was obtained by dividing the root dry biomass by the shoot dry biomass (RDB/SDB).

\subsection{Leaf Analysis}

The samples collected to evaluate the dry biomass were ground in a Wiley mill and sent to the Laboratory of Leaf Analysis of the Chemistry Department of UFLA to determine the N, P, K, Ca, Mg, S, B, Cu, Mn, Zn, and Fe contents using the methodology proposed by Malavolta, Vitti, and Oliveira (1997). 


\subsection{Extraction and Chemical Analyses of the Essential Oil}

The $C$. flexuosus essential oil was extracted by hydrodistillation in a modified Clevenger apparatus using a $10 \mathrm{~g}$ sample of leaf dry biomass in $1 \mathrm{~L}$ of distilled water for $90 \mathrm{~min}$. The essential oil was purified by liquid-liquid partition with dichloromethane $(3 \times 5 \mathrm{~mL})$. The organic phase was combined and treated with approximately $5 \mathrm{~g}$ of anhydrous magnesium sulfate for $30 \mathrm{~min}$. Next, the solution was filtered, and the solvent evaporated at room temperature under a gas exhaust hood. Five replicates were performed per essential oil treatment from samples composed of dry biomass and stored in amber flasks. The essential oil content (\%) and yield (mg plant $\left.{ }^{-1}\right)$ were determined. Each sample's content represents the oil weight (mg) in $100 \mathrm{mg}$ of leaf dry biomass, and the yield is the product of the content multiplied by the leaf dry biomass.

For the quantitative analysis, the essential oil was analyzed in an Agilent 5890A system equipped with a flame ionization detector (FID), using an HP-5MS column (30 cm long $\times 250 \mu \mathrm{m}$ internal diameter $\times 0.25 \mu \mathrm{m}$ thick). Helium was used as the carrier gas with a flow rate of $1.0 \mathrm{~mL} \mathrm{~min}^{-1}$. The injector and detector temperatures were 220 and $240{ }^{\circ} \mathrm{C}$, respectively. The initial oven temperature was $60^{\circ} \mathrm{C}$, which was maintained for 1 min, followed by a temperature increase of $3{ }^{\circ} \mathrm{C} \mathrm{min}^{-1}$ to $150{ }^{\circ} \mathrm{C}$, then subsequently increased at $10{ }^{\circ} \mathrm{C} \mathrm{min}^{-1}$ to $250{ }^{\circ} \mathrm{C}$. The essential oil was diluted in ethyl acetate $(1 \%, \mathrm{v} / \mathrm{v})$, and $1 \mu \mathrm{l}$ was injected in split mode at a 1:50 ratio. The analyses were performed in triplicate, and the results are expressed as the mean percentage of the relative normalized area of the chromatographic peaks \pm standard deviation.

Qualitative analyses were performed on an Agilent ${ }^{\circledR} 7890$ A Chromatograph coupled to an Agilent ${ }^{\circledR}$ MSD 5975C mass selective detector (Agilent Technologies, California, USA) operated by electronic impact ionization at $70 \mathrm{eV}$ in sweep mode at a speed of $1.0 \mathrm{scan} / \mathrm{s}$, with a mass acquisition interval of $40-400 \mathrm{~m} / \mathrm{z}$. The operating conditions were the same as those used in gas chromatography-flame ionization detector (GC-FID) analyses. The components were identified by comparing their retention indices $\left(\mathrm{IK}_{\mathrm{c}}\right)$ calculated using mass spectra data and retention indices (IK) from the literature (Davies, 1990; Adams, 2007) and by comparing mass spectra from the NIST/EPA/NHI library database (NIST, 2008) and the literature (ADAMS, 2007). The retention indices were calculated using the Van den Dool and Kratz equation (1963), and retention indices cited in the literature were used for the attributions (Adams, 2007).

\subsection{Statistical Analysis}

Statistica ${ }^{\circledR}$ software, version 13.3 (StatSoft; Tulsa, OK, USA), was used to statistically analyze the experimental data. The observed values were submitted to analysis of variance (ANOVA, $p<0.05$ ) and compared using Tukey's test $(\mathrm{p}<0.05)$. Principal component analysis $(\mathrm{PCA})$ was used to study the major essential oil compounds.

\section{Results and Discussion}

Dry biomass production was higher in plants grown in complete nutrient solution. All means of the variables analyzed differed statistically due to the macronutrient suppression (Table 1). The number of tillers under $\mathrm{S}$ suppression (67) was similar to that of the complete solution (76); however, the other suppressions greatly reduced the $C$. flexuosus tillering capacity (Table 1). The greatest limitation to root growth (RDB) relative to the complete treatment was verified by suppressing $\mathrm{K}, \mathrm{Ca}$, and $\mathrm{Mg}$, with reductions of $93 \%, 75 \%$, and $89 \%$, respectively. However, RDB was unaffected by the absence of P and S. Daflon et al. (2014) also observed that S suppression did not reduce the dry matter in Coriandrum sativum roots.

The LDB and LBDB production were more affected by N, K, and Mg macronutrients (Table 1). Consequently, SDB presented greater limitations after suppressing the same nutrients. The reduced dry biomass production was related to these nutrients' functions in the photosynthetic apparatus structures and photosynthesis. Nitrogen deficiency inhibits plant growth because $\mathrm{N}$ is a constituent of many plant cell components, including amino acids and nucleic acids (Carvalho et al., 2016). Potassium acts mainly in regulating the osmotic potential, maintaining the $\mathrm{pH}$ in the cell, and controlling the stomata opening and closing (Malavolta, 2006). Magnesium is the central element of the chlorophyll molecule (Shaul, 2002).

All treatments with macronutrient suppression resulted in a total dry biomass lower than that of the complete treatment (Table 1). The nutrient limitation order for TDB was $\mathrm{K}=\mathrm{Mg}>\mathrm{N}=\mathrm{Ca}=\mathrm{P}>\mathrm{S}$. The relative total dry biomass (RPTDB) produced was lower after suppressing $\mathrm{K}(6.5 \%)$ and $\mathrm{Mg}(8.5 \%)$, which reduced the biomass gained by $93.5 \%$ and $91.5 \%$, respectively. Puga et al. (2010) studied the effect of macronutrient suppression on chicory and also verified better total dry biomass yield in the complete solution and when suppressing sulfur. Per Sanchez and Uehara (1980), dry mass production below $40 \%$ relative to the complete treatment is considered a severe deficiency. Thus, suppressing N, P, K, Ca, and Mg induced severe deficiencies in C. flexuosus at 90 days. 
Table 1. Mean values of the number of tillers (NT), root dry biomass (RDB), leaf dry biomass (LDB), leaf base dry biomass (LBDB), shoot dry biomass (SDB), total dry biomass (TDB), relative production of total dry biomass (RPTDB), and root-to-shoot ratio (R:S) in C. flexuosus under macronutrient suppression in a hydroponic culture

\begin{tabular}{|c|c|c|c|c|c|c|c|c|}
\hline & NT & RDB & LDB & LBDB & SDB & TDB & RPTDB & $\mathrm{R}: \mathrm{S}$ \\
\hline & & (------. & ----------- & - g plan & -------- & -------------- & $\%$ & \\
\hline Complete & $76 a^{*}$ & $13.22 \mathrm{a}$ & $44.24 \mathrm{a}$ & $7.56 \mathrm{a}$ & $51.80 \mathrm{a}$ & $65.02 \mathrm{a}$ & 100 & $0.26 \mathrm{c}$ \\
\hline$-\mathrm{N}$ & $18 \mathrm{~b}$ & $6.36 \mathrm{~b}$ & $5.47 \mathrm{~d}$ & $2.80 \mathrm{~b}$ & $8.27 \mathrm{~d}$ & $14.36 \mathrm{c}$ & 22.1 & $0.76 \mathrm{~b}$ \\
\hline$-\mathrm{P}$ & $23 \mathrm{~b}$ & $12.53 \mathrm{a}$ & $8.76 \mathrm{c}$ & $3.81 \mathrm{~b}$ & $12.58 \mathrm{c}$ & $25.11 \mathrm{c}$ & 38.6 & $1.00 \mathrm{a}$ \\
\hline$-K$ & $7 \mathrm{~b}$ & $0.94 \mathrm{c}$ & $2.40 \mathrm{~d}$ & $0.91 \mathrm{c}$ & $3.31 \mathrm{~d}$ & $4.25 \mathrm{~d}$ & 6.5 & $0.29 \mathrm{c}$ \\
\hline$-\mathrm{Ca}$ & $20 \mathrm{~b}$ & $3.37 \mathrm{c}$ & $10.38 \mathrm{c}$ & $3.23 \mathrm{~b}$ & $13.60 \mathrm{c}$ & $16.97 \mathrm{c}$ & 26.1 & $0.24 \mathrm{c}$ \\
\hline$-\mathrm{Mg}$ & $11 \mathrm{~b}$ & $1.39 \mathrm{c}$ & $3.12 \mathrm{~d}$ & $1.03 \mathrm{c}$ & $4.15 \mathrm{~d}$ & $5.54 \mathrm{~d}$ & 8.5 & $0.34 \mathrm{c}$ \\
\hline$-S$ & $67 a$ & $12.35 \mathrm{a}$ & $36.77 \mathrm{~b}$ & $6.04 \mathrm{a}$ & $42.76 \mathrm{~b}$ & $55.11 \mathrm{~b}$ & 84.8 & $0.29 \mathrm{c}$ \\
\hline $\mathrm{CV}(\%)$ & 27.15 & 28.55 & 22.17 & 36.28 & 24.41 & 22.41 & - & 24.19 \\
\hline
\end{tabular}

Note. * Means followed by the same letter in a row do not differ statistically from each other by Tukey's test at $5 \%$ probability.

The R:S ratio was higher in plants grown under phosphorus suppression, followed by nitrogen. The other treatments presented smaller and statistically similar values (Table 1). This result indicates that the complete solution and the $\mathrm{K}, \mathrm{Ca}, \mathrm{Mg}$, and $\mathrm{S}$ suppressions direct the biomass distribution to the plant shoot.

Analysis of the leaves (Table 2) revealed that the percentage of each suppressed macronutrient, except S, was below the limit that Malavolta, Vitti, and Oliveira (1997) suggested for grasses. In the sulfur suppression treatment, the leaves' nutrient content $(0.20 \%)$ was similar to that of the complete solution $(0.22 \%)$. Sulfur mobility in the plant is practically nonexistent, in addition to being a constituent of proteins, essential amino acids, cell membranes and other compounds (Marschner, 2012). Thus, early incorporation of S into organic molecules that are essential to the plant's initial development may have occurred during the adaptation period.

Table 2. Leaf analysis of C. flexuosus under macronutrient suppression in a hydroponic culture for 90 days

\begin{tabular}{|c|c|c|c|c|c|c|c|c|c|c|c|c|}
\hline & & $\mathrm{N}$ & $\mathrm{P}$ & $\mathrm{K}$ & $\mathrm{Ca}$ & $\mathrm{Mg}$ & $\mathrm{S}$ & $\mathrm{B}$ & $\mathrm{Cu}$ & $\mathrm{Mn}$ & $\mathrm{Zn}$ & $\mathrm{Fe}$ \\
\hline & & \multicolumn{6}{|c|}{ 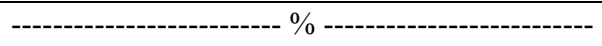 } & \multicolumn{5}{|c|}{ 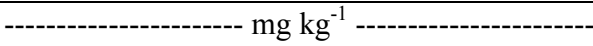 } \\
\hline \multicolumn{2}{|l|}{ Complete } & 2.19 & 0.99 & 2.40 & 0.35 & 0.25 & 0.22 & 19.18 & 7.39 & 37.58 & 12.33 & 165.23 \\
\hline \multicolumn{2}{|l|}{$-\mathrm{N}$} & 0.72 & 0.72 & 1.77 & 0.24 & 0.17 & 0.42 & 38.19 & 3.89 & 146.12 & 17.69 & 263.93 \\
\hline \multicolumn{2}{|l|}{$-\mathrm{P}$} & 0.66 & 0.04 & 1.66 & 0.98 & 0.33 & 0.28 & 52.53 & 4.28 & 50.72 & 13.29 & 307.41 \\
\hline \multicolumn{2}{|l|}{$-K$} & 2.46 & 1.99 & 0.19 & 0.86 & 0.59 & 0.43 & 41.69 & 8.75 & 70.73 & 18.55 & 339.12 \\
\hline \multicolumn{2}{|l|}{$-\mathrm{Ca}$} & 2.26 & 1.73 & 2.83 & 0.09 & 0.51 & 0.43 & 65.03 & 7.24 & 95.31 & 16.74 & 251.64 \\
\hline \multicolumn{2}{|l|}{$-\mathrm{Mg}$} & 1.98 & 1.29 & 2.60 & 0.86 & 0.08 & 0.21 & 44.52 & 6.27 & 64.83 & 13.79 & 244.29 \\
\hline \multicolumn{2}{|l|}{$-S$} & 2.32 & 1.23 & 2.17 & 0.49 & 0.32 & 0.20 & 34.19 & 8.37 & 46.12 & 12.09 & 153.78 \\
\hline \multirow{2}{*}{$\begin{array}{l}\text { Range of } \\
\text { sufficiency* }\end{array}$} & Low & 1.2 & 0.08 & 1.10 & 0.3 & 0.1 & 0.1 & 15 & 5 & 80 & 20 & 100 \\
\hline & High & 1.5 & 0.12 & 1.50 & 0.6 & 0.2 & 0.2 & 30 & 15 & 300 & 50 & 200 \\
\hline
\end{tabular}

Note. * Malavolta et al. (1997).

Notably, $\mathrm{P}$ suppression considerably reduced the leaf $\mathrm{N}$ content $(0.66 \%)$ compared with that of the complete solution (2.19\%). The opposite relationship was also verified, where $\mathrm{N}$ suppression reduced the $\mathrm{P}$ content relative to the other treatments. Ågren, Wetterstedt, and Billberger (2012) reported that nitrogen fertilization may stimulate extracellular phosphatase activity and thus increase P uptake. Daflon et al. (2014) reported the importance of evaluating the nutritional contents in plant tissues. These researchers observed that potassium content in plants treated with $\mathrm{K}$ suppression was lower than that in the complete treatment even without visual symptoms. Therefore, leaf analyses enable more precise inferences from the data. The symptoms of N, P, Ca, and S deficiencies in the leaves and roots were photographed at 90 days after applying the treatments (Figure 1). The plants with $\mathrm{K}$ and $\mathrm{Mg}$ suppression died after 35 days; thus, they could not be recorded at the end of the experimental period. 

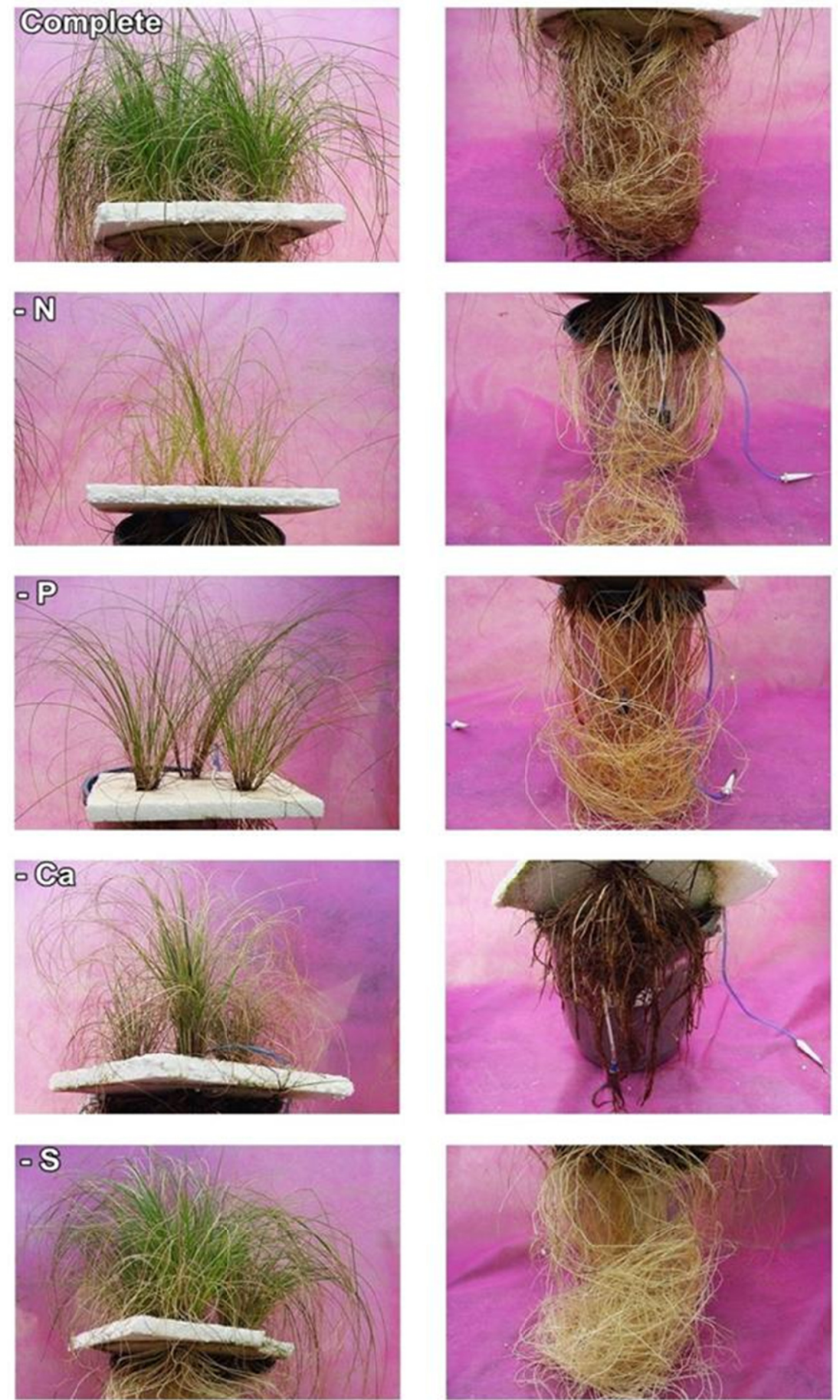

Figure 1.Visual diagnosis of the shoot and root system of $C$. flexuosus cultivated for 90 days in a complete solution and under $\mathrm{N}, \mathrm{P}, \mathrm{Ca}$, and $\mathrm{S}$ suppressions

Over the 90-day experimental period, the complete solution provided plants with darker green leaves and more abundant root systems than those of the other treatments (Figure 1). Nitrogen suppression resulted in generalized chlorosis of old leaves after 40 days. The entire plant became chlorotic, with fewer tillers and a less abundant root system with the culture advance. Generalized chlorosis was observed in old leaves due to the plants' lower chlorophyll production and high nutrient mobility (Marschner, 2012).

P-deficient plants also showed smaller and fewer tillers. After 30 days, the leaves appeared dark green (Figure 1). Coelho et al. (2011) observed that P-deficient Tagetes erecta presented necroses on the edges of new leaves, browning leaf blades and smaller young leaves. As with $\mathrm{K}$ suppression, the absence of Mg resulted in the plants 
dying at 35 days. Initially, the leaves developed typical symptoms with internerval chlorosis of the old leaves. According to Taiz et al. (2017), this type of chlorosis occurs because chlorophyll in the vascular bundles remains unchanged for longer periods than does chlorophyll in the cells between bundles. New chlorotic leaves and abundant root systems with whitish coloring were observed with S suppression at the end of the culturing. Per Marschner (2012), S is a constituent element of essential amino acids and has little mobility; thus, its symptoms occur in younger leaves.

In addition, suppressing macronutrients in the nutrient solution influenced the content and yield of the C.flexuosus essential oil (Figure 2). The highest mean essential oil content was verified for sulfur suppression (1.92\%), followed by the complete solution (1.67\%) (Figure 2a). The increased essential oil production after S suppression may be related to its incorporation during the plants' adaptation period to the nutrient solution. This leaf S content was within the content suggested by Malavolta, Vitti, and Oliveira (1997). Considering that $\mathrm{S}$ is related to the primary metabolism's protein, its absence did not reduce the secondary metabolite production. In turn, the nutrient solution with $\mathrm{N}$ suppression was the solution that most affected the essential oil content, which was reduced by $38 \%$.
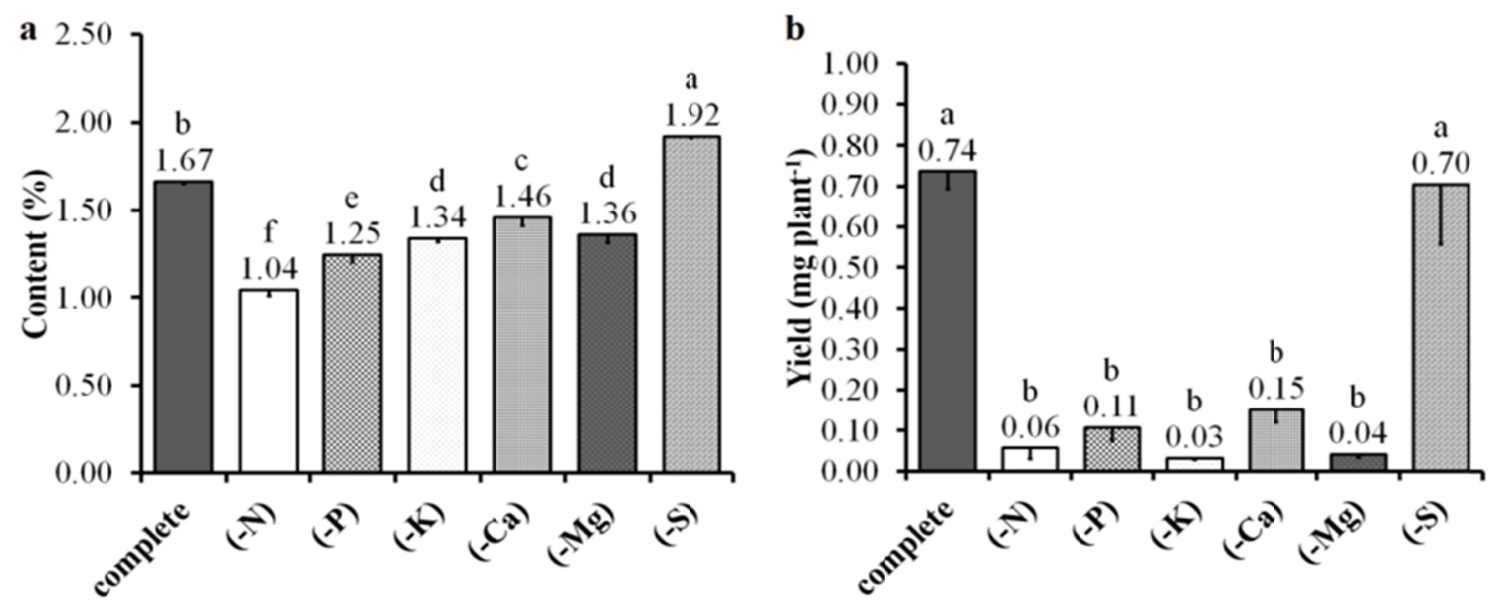

Figure 2. Mean values of a: content (\%) and b: yield $\left(\mathrm{mg} \mathrm{plant}^{-1}\right)$ of $C$. flexuosus essential oil under macronutrient suppression in a hydroponic culture. Means followed by the same letter do not differ statistically from each other by Tukey's test at $5 \%$ probability

Despite the higher essential oil content after suppressing $\mathrm{S}$, the complete solution resulted in an oil yield statistically similar to that of the $\mathrm{S}$ suppression treatment (Figure 2b). In calculating the oil yield, the oil content is related to the leaf dry biomass production. The complete solution provided the highest mean LDB. Compared with the complete solution, the $\mathrm{N}, \mathrm{P}, \mathrm{K}, \mathrm{Ca}$, and $\mathrm{Mg}$ suppressions provided lower essential oil yields, which were reduced by $92,85,96,80$, and $95 \%$, respectively.

Five major constituents were identified by chemically analyzing the C. flexuosus essential oil: linalool (3.08-3.59\%), neral (9.54-27.79\%), geraniol (3.31-16.21\%), geranial (14.31-50.83\%), and geranial acetate $(6.56-45.50 \%)$ (Table 3).

Table 3. Content \pm standard deviation (\%) of the major chemical constituents of $C$. flexuosus essential oil

\begin{tabular}{llllllll}
\hline Constituents & Complete & $-\mathrm{N}$ & $-\mathrm{P}$ & $-\mathrm{K}$ & $-\mathrm{Ca}$ & $-\mathrm{Mg}$ & $-\mathrm{S}$ \\
\hline Linalool & $3.50 \pm 0.00$ & $3.08 \pm 0.02$ & $3.30 \pm 0.00$ & $4.88 \pm 0.03$ & $3.59 \pm 0.04$ & $3.42 \pm 0.00$ & $3.47 \pm 0.00$ \\
Neral & $14.99 \pm 0.05$ & $21.54 \pm 0.08$ & $27.79 \pm 0.09$ & $10.62 \pm 0.03$ & $9.54 \pm 0.07$ & $20.59 \pm 0.02$ & $18.86 \pm 0.01$ \\
Geraniol & $12.73 \pm 0.04$ & $4.44 \pm 0.03$ & $3.31 \pm 0.00$ & $15.99 \pm 0.00$ & $16.13 \pm 0.13$ & $16.21 \pm 0.02$ & $11.23 \pm 0.01$ \\
Geranial & $23.31 \pm 0.09$ & $48.36 \pm 0.14$ & $50.83 \pm 0.07$ & $15.55 \pm 0.10$ & $14.31 \pm 0.10$ & $33.77 \pm 0.00$ & $30.11 \pm 0.01$ \\
Geranyl acetate & $37.61 \pm 0.13$ & $10.06 \pm 0.05$ & $6.56 \pm 0.01$ & $45.50 \pm 0.08$ & $16.50 \pm 0.09$ & $12.12 \pm 0.00$ & $29.32 \pm 0.02$ \\
Total (\%) & 92.14 & 87.48 & 91.79 & 92.54 & 60.07 & 86.11 & 92.99 \\
\hline
\end{tabular}


Suppressing the nutrients promoted quantitative changes in the essential oil's chemical composition. Principal component analysis (PCA) of the four major chemical compounds and citral (PC1+PC2) showed an approximate adjustment of $94.91 \%$ (Figure 3). Notably, neral, geranial and citral were positively correlated with each other and negatively correlated with geraniol. Ganjewala and Luthra (2010) studied the biosynthetic route of C. flexuosus and concluded that geraniol is oxidized via geraniol dehydrogenase to produce geranial, which is converted to neral by an isomerase. Citral monoterpene is a racemic mixture of the geranial and neral isomers (Gupta \& Ganjewala, 2015).
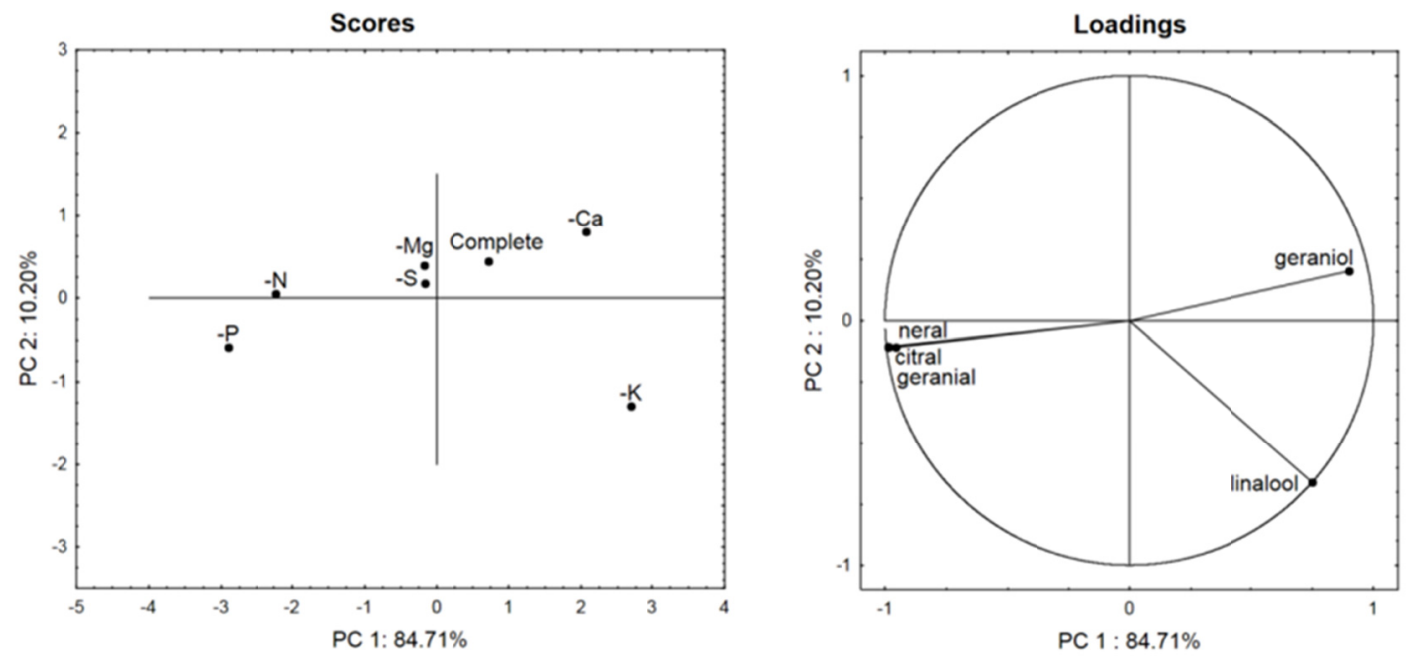

Figure 3. Principal component analysis (PCA) of the major constituents of C. flexuosus essential oil

The neral, geranial and citral levels were increased in the plants cultivated under phosphorus and nitrogen suppression. The absence of $\mathrm{K}$ in the nutrient solution positively influenced the linalool and geranyl acetate contents. Calcium suppression favored a higher geraniol content (Figure 3). These nutrients are related in their synthesis of secondary compounds as enzyme catalysts or their presence in their structure. Alvarenga et al. (2015) also verified quantitative changes in the major components of Achillea millefolium.

\section{Conclusions}

Macronutrient suppression in the nutrient solution of Cymbopogon flexuosus resulted in visual symptoms of the plant's nutritional deficiency; these symptoms are also common in other species. Potassium and magnesium are the most limiting macronutrients for biomass production, and the limiting order of TDB is $\mathrm{K}=\mathrm{Mg}>\mathrm{N}=\mathrm{Ca}=\mathrm{P}>$ $\mathrm{S}$. The highest essential oil content occurred under sulfur suppression, and a similar yield was verified for the complete solution. Chemical analysis of the essential oil was quantitatively altered in the hydroponic culture. P and $\mathrm{N}$ suppression promoted an increase in citral contents.

\section{Acknowledgements}

This study was financed in parts by National Council for Scientific and Technological Development (CNPq-Conselho Nacional de Desenvolvimento Científico e Tecnológico), the Minas Gerais State Research Foundation (FAPEMIG-Fundação de Pesquisa do Estado de Minas Gerais), and the Coordination for the Improvement of Higher Education Personnel (CAPES-Coordenação de Aperfeiçoamento de Pessoal de Nível Superior-Brasil (CAPES-Finance Code 001).

\section{References}

Adams, R. P. (2007). Identification of essential oils by ion trap mass spectroscopy. Academic Press.

Adukwu, E. C., Bowles, M., Edwards-Jones, V., \& Bone, H. (2016). Antimicrobial activity, cytotoxicity and chemical analysis of lemongrass essential oil (Cymbopogon flexuosus) and pure citral. Appl Microbiol Biotechnol, 100(22), 9619-9627. https://doi.org/10.1007/s00253-016-7807-y

Ågren, G. I., Wetterstedt, J., \& Billberger, M. F. (2012). Nutrient limitation on terrestrial plant growth-modeling the interaction between nitrogen and phosphorus. New Phytologist, 194(4), 953-960. https://doi.org/ $10.1111 / \mathrm{j} .1469-8137.2012 .04116 . x$ 
Alvarenga, I. C. A., Boldrin, P. F., Pacheco, F. V., Silva, S. T., Bertolucci, S. K. V., \& Pinto, J. E. B. P. (2015). Effects on growth, essential oil content and composition of the volatile fraction of Achillea millefolium $\mathrm{L}$. cultivated in hydroponic systems deficient in macro-and microelements. Scientia Horticulturae, 197, 329-338. https://doi.org/10.1016/j.scienta.2015.09.046

Alves, A. U., Prado, R. d. M., Gondim, A. R. d. O., Fonseca, I. M., \& Cecílio Filho, A. B. (2008). Desenvolvimento e estado nutricional da beterraba em função da omisão de nutrientes. Horticultura Brasileira, 26, 292-295. https://doi.org/10.1590/S0102-05362008000200033

Amaral, J. F. T. d., Fonseca, A. F. A. d., Martinez, H. E. P., Pereira, P. R., \& Fontes, P. C. R. (2015). Deficiências De Macronutrientes, Fe Eb Em Manjericão (Ocimum sp.), Em Cultivo Hidropônico. Ceres, 46(265).

Andriolo, J. L., Bonini, J. V., \& Boemo, M. P. (2002). Acumulação de matéria seca e rendimento de frutos de morangueiro cultivado em substrato com diferentes soluções nutritivas. Horticultura Brasileira, 20, 24-27. https://doi.org/10.1590/S0102-05362002000100004

Benedetti, E. L., Wink, C., Santin, D., Sereda, F., Roveda, L. F., \& Serrat, B. M. (2009). Crescimento e sintomas em mudas de espinheira-santa com omissão de nitrogênio, fósforo e potássio. Floresta, 39(2). https://doi.org/10.5380/rf.v39i2.14560

Carvalho, A. A. d., Bertolucci, S. K. V., Figueiredo, F. C., \& Pinto, J. E. B. P. (2016). Crescimento e composição da fração volátil de Mentha arvensis L. cultivada em solução nutritiva com omissão de nutrientes. Revista Brasileira de Plantas Medicinais, 18(3), 677-684.

Coelho, L. C., Kawamoto, L. S., Rodas, C. L., de Souza, G. A., de Pinho, P. J., \& de Carvalho, J. G. (2011). Caracterização de sintomas visuais, parâmetros de crescimento e desenvolvimento de Tagetes erecta sob deficiências nutricionais. Agrarian, 4(12), 113-122.

da Silva Júnior, M. L., Seabra, D. A., de Melo, V. S., Santos, M. M. d. L. S., \& dos Santos, P. C. T. C. (2011). Crescimento, composição mineral e sintomas de deficiências de pariri cultivado sob omissão de macronutrientes. Revista de Ciências Agrárias/Amazonian Journal of Agricultural and Environmental Sciences, 48(1), 85-98.

Daflon, D. G., Freitas, M. S. M., de Carvalho, A. J. C., Monnerat, P. H., \& Prins, C. L. (2014). Sintomas visuais de deficiência de macronutrientes e boro em coentro. Horticultura Brasileira, 32(01). https://doi.org/ $10.1590 / \mathrm{S} 0102-05362014000100005$

Davies, N. W. (1990). Gas chromatographic retention indices of monoterpenes and sesquiterpenes on methyl silicon and Carbowax 20M phases. Journal of Chromatography, A 503, 1-24. https://doi.org/10.1016/ S0021-9673(01)81487-4

Ganjewala, D., \& Luthra, R. (2010). Essential oil biosynthesis and regulation in the genus Cymbopogon. Nat Prod Commun, 5(1), 163-172.

Gupta, A. K., \& Ganjewala, D. (2015). A study on biosynthesis of "citral" in lemongrass (C-flexuosus) cv. Suvarna. Acta Physiologiae Plantarum, 37(11). https://doi.org/10.1007/s11738-015-1989-2

Hoagland, D. R., \& Arnon, D. I. (1950). The water-culture method for growing plants without soil (p. 347). California Agricultural Experiment Station.

Joyce, B. L., Zheljazkov, V. D., Sykes, R., Cantrell, C. L., Hamilton, C., Mann, D. G., ... Stewart, C. N., Jr. (2015). Ethanol and High-Value Terpene Co-Production from Lignocellulosic Biomass of Cymbopogon flexuosus and Cymbopogon martinii. PLoS One, 10(10), e0139195. https://doi.org/10.1371/journal.pone. 0139195

Maia, J. T. L. S., Leite, R. S., Maia, C. I., Feres, A., \& Jones, K. M. (2014). Plantas Medicinais em Hidroponia: Uma Revisão de Literatura. Revista Bionorte, 3(1).

Malavolta, E. (2006). Manual de nutrição mineral de plantas. Agronômica Ceres.

Malavolta, E., Vitti, G. C., \& Oliveira, S. A. d. (1997). Avaliação do estado nutricional das plantas: Princípios e aplicações.

Marigowda, V. J. H. M. A., Mn, S., \& Saraswathi, T. (2016). Studies on antibacterial, antioxidant and anticancerous activity using essential oil from Cymbopogon flexuosus (stapf). International Journal of Advanced Research, 4, 1324-1341. https://doi.org/10.21474/IJAR01/2526

Marschner, H. (2012). Marschner's mineral nutrition of higher plants. Academic press. 
May, A., Bovi, O. A., Maia, N. B., Moraes, A. R. d., Pinheiro, M. Q., \& Mario, M. d. (2008). Influência do intervalo entre cortes sobre a produção de biomassa de duas espécies de capim limão. Horticultura Brasileira, 26, 379-382. https://doi.org/10.1590/S0102-05362008000300017

Meena, S., Kumar, S. R., Venkata Rao, D. K., Dwivedi, V., Shilpashree, H. B., Rastogi, S., ... Nagegowda, D. A. (2016). De Novo Sequencing and Analysis of Lemongrass Transcriptome Provide First Insights into the Essential Oil Biosynthesis of Aromatic Grasses. Front Plant Sci, 7, 1129. https://doi.org/10.3389/fpls. 2016.01129

NIST. (2008). PC version 2.0 of the NIST/EPA/NIH Mass Spectral Library. Gaithersburg: U.S.

Oliveira, A. R. D., Oliveira, S. A. D., Giordano, L. D. B., \& Goedert, W. J. (2009). Absorção de nutrientes e resposta à adubação em linhagens de tomateiro. Horticultura Brasileira, 27, 498-504. https://doi.org/ $10.1590 / \mathrm{S} 0102-05362009000400016$

Puga, A. P., de Mello Prado, R., Correia, M. A. R., \& Almeida, T. B. (2010). Omissão de macronutrientes no crescimento e no estado nutricional da chicória cultivada em solução nutritiva. Agrarian, 3(7), 56-62.

Sanchez, P. A., \& Uehara, G. (1980). Management considerations for acid soils with high phosphorus fixation capacity. In F. E. Khasawneh, H. Abdelgawad, \& H. Abdelgawad (Eds.), The role of phosphorus in agriculture (pp. 471-514). Madison: ASA.

Sharma, P. R., Mondhe, D. M., Muthiah, S., Pal, H. C., Shahi, A. K., Saxena, A. K., \& Qazi, G. N. (2009). Anticancer activity of an essential oil from Cymbopogon flexuosus. Chem Biol Interact, 179(2-3), 160-168. https://doi.org/10.1016/j.cbi.2008.12.004

Shaul, O. (2002). Magnesium transport and function in plants: The tip of the iceberg. Biometals, 15(3), 307-321. https://doi.org/10.1023/A:1016091118585

Taiz, L., \& Zeiger, E. (2017). Fisiologia vegetal. Fisiologia vegetal: Artmed.

Van den Dool, H., \& Kratz, P. D. (1963). A generalization of the retention index system including linear temperature programmed gas-liquid partition chromatography. Journal of Chromatography A, 11, 463-471. https://doi.org/10.1016/S0021-9673(01)80947-X

Vera, S. S., Zambrano, D. F., Mendez-Sanchez, S. C., Rodriguez-Sanabria, F., Stashenko, E. E., \& Duque Luna, J. E. (2014). Essential oils with insecticidal activity against larvae of Aedes aegypti (Diptera: Culicidae). Parasitol Res, 113(7), 2647-2654. https://doi.org/10.1007/s00436-014-3917-6

\section{Copyrights}

Copyright for this article is retained by the author(s), with first publication rights granted to the journal.

This is an open-access article distributed under the terms and conditions of the Creative Commons Attribution license (http://creativecommons.org/licenses/by/4.0/). 